\section{A Season of Service: Introducing Service Learning into the Liberal Arts Curriculum}

\author{
Benjamin R. Barber, Rutgers University \\ Richard Battistoni, Rutgers University
}

where near the $65 \%$ or better rates of participation that were typical before the 1970 s.

These observations notwithstanding, there are ample signs of burgeoning interest in service in the

We live in times when rights and obligations have become uncoupled. Individuals regard themselves almost exclusively as private persons with responsibilities only to family and job, yet possessing endless rights against a distant and alien state in relationship to which they think of themselves, at best, as watchdogs and clients and, at worst, as adversaries and victims. The idea of service to country or to the institutions by which rights and liberty are legitimized and sustained has fairly vanished.

In the last decade, right up until the recent election, what was once a certain healthy distrust of outsized or overbureaucratized government had become a zany antipathy towards all government, so that not even public schooling or progressive taxation were necessarily to be regarded as legitimate. The defeat of President Bush in the recent election seems to mean a defeat for privatization and exclusively market thinking and may reopen the way to seeing in government a public ally of public goods, but the 1980s has taken its toll. There has been a dispiriting erosion of democratic civic culture with a corresponding growth in civic apathy, resentment, even anger. Participation in voting, itself the least of citizenship's obligations, fell. In 1988, over 91 million citizens eligible to vote failed to do so, and young people, arguably those most benefitted by the right to vote, participated at the lowest rate of any Americans. Happily, the overall percentage improved to $55 \%$ in the 1992 presidential elections, with an encouraging jump in college-age participation, but even these improved numbers come no-

. . service is often
segregated from civil
responsibility, and is
instead associated with
altruism or charity-a
supererogatory activity of
good men and women
rather than an obligatory
activity of responsible
citizens.

United States today, and some evidence that students have increased their level of political engagement. Yet neither this engagement nor philanthropic community service are closely tied to citizenship. Indeed, service is often segregated from civic responsibility, and is instead associated with altruism or charity-a supererogatory activity of good men and women rather than an obligatory activity of responsible citizens. As persons who see themselves as spectators to politics and clients of governments to which they otherwise feel little responsibility, it is hardly a wonder that many young people regard service exclusively as an alternative to government $-a$ way to solve problems government cannot solve, a market mechanism in which volunteers deal one on one with issues some might regard as infrastructural and susceptible only to collective action and common solutions.

Many of the bills revolving around service offered in the last session of Congress embraced a spirit of private sector voluntarism that seems at best indifferent and at worst hostile to the responsibilities (and rights) of citizenship. A successful resuscitation of the idea of service is then unlikely to proceed without a concomitant refurbishing of the theory and practice of democratic citizenship. Successful programs of community service and service learning must finally be grounded in democracy. President Clinton's Office of National Service has forged impressive policy links between service and citizen education, and there is hope that in his challenge to young Americans, the president will nourish a new spirit of civic activity.

This spirit of citizenship revitalized and the idea of service recoupled to democracy have guided the pioneering experiment in civic education and community service initiated at Rutgers University just four years ago. In the spring of 1988, President Edward Bloustein gave a commencement address that focused on the pathologies of prejudice and radical individualism that had created a sense of crisis in the nation at large and had manifested themselves as particular problems for the Rutgers University community-where several students had died in alcohol-related incidents. Remembering his own wartime experience in an army that was just beginning to have a multicultural look, Bloustein proposed a mandatory program of citizen education and community service as a graduation requirement for all students at Rutgers (the State University of New Jersey).

President Bloustein appointed a committee chaired by Benjamin Barber charged with exploring the idea of service learning in the academy, and with developing a program through which it could be realized. Comprised of board of 
governor members, faculty, students, and administrators, this committee developed a plan for a flexible, multicourse program that has now been in place at Rutgers for three years-overseen by Barber's Walt Whitman Center for the Culture and Politics of Democracy, and directed by Richard Battistoni. Key to the Rutgers program is integration of service into a serious learning context. As the New York Times Magazine (September 27, 1992) commented in a recent article, "The Rutgers program is the only one at a large state university that insists student volunteers be familiar with essays on democratic theory and practice like William James's 'Moral Equivalent of War,' and Carole Pateman's 'Feminism and Democracy.' " And recently, the Rutgers Civic Education and Community Service Program was recognized as a national model by President Clinton when he visited the campus March 1, 1993, to deliver his major policy address on national service.

Our experience at Rutgers and at Baylor University, where Battistoni introduced a service learning program in 1991, has taught us important lessons-not necessarily about what a perfect service learning program looks like, but about what the crucial questions and choices are that colleges and universities thinking about education-based community service need to raise. What follows then is a discussion of these ten crucial choices which we hope will be useful to our colleagues in and out of political science looking for ways to return the American educational mission to its democratic roots.

\section{Ten Crucial Choices}

Any teaching community wishing to reflect on and develop a service learning program will need to respond to many of the following questions. Our discussion here reflects our own convictions about the right choices, and tries to do justice to the complexity of the issues.

1. Should service be educationbased or extracurricular?

2. Should it be mandatory or voluntary?

3. Should it be civic or philan- thropic?

4. Should it be for credit or not?

5. Should it be offered as a single course or as a multi-course program?

6. Should the community be a "client" or a "partner in education"?

7. Should students serve in group teams or as individuals?

8. Should the faculty also do community service?

9. Should the pedagogy of service emphasize patriotism and citizenship or critical thinking?

10. Should students participate in the planning process?

\section{Education-Based or Extracurricular?}

Community service in school settings began as extracurricular activity. The hope was that service itself would contribute to the education of the young without any explicit classroom or academic work. National organizations like Youth Service America, the Campus Outreach Opportunity League, and Campus Compact were originally geared to encouraging service outside of formal curricula and requirements. This had the advantage of permitting service programs to grow without depending on faculty or administration decisions, and it has minimized program costs. It also placed the emphasis on service rendered to the community, and took for granted pedagogical benefits to students. It was associated with voluntarism and philanthropy, and was only weakly linked (if at all) to civic responsibility and citizen education.

The Rutgers program began with an alternative thesis: that educational institutions are learning communities, not service agencies, and that the primary justification for service programs has to be pedagogical. This suggested the necessity of bringing service experience back into the classroom-treating community service as a practicum integral to a class-based learning experience. Rather than polarizing experiential and classroom learning, this approach permitted the two to be married in a fashion where critical reading and discussion could inform service, and where service could provide an experiential base for critical learning and help make it real.

This approach also put service learning on a par with other academic courses and removed it from the second-class academic citizenship associated with extracurricular activities and the "touchy-feely" therapeutic mode too often ascribed to human service learning.

\section{Mandatory or Voluntary?}

The extracurricular orientation of traditional service programs has often yielded a philanthropic view of service, and that view in turn is linked to voluntarism. After all, if the point was to encourage "voluntarism," service could hardly be coerced or mandated. But once community service is placed in a learning context and integrated as a practicum into serious academic work, it can be required just as any other academic sequence might be required. If civic literacy is analogous to mathematical or cultural or scientific literacy, then requiring civic literacy presents no theoretical difficulties of the kind facing voluntarism.

Nonetheless, it has been our experience that the struggle to require service can in practice impede progress towards the goals the requirement is meant to serve. At both Rutgers and Baylor, the initial commitment to a mandatory requirement generated extended controversy and a sufficient tumult among a loud minority of students and faculty to divert attention away from the real goals of civic learning and the substantive achievements of actual service learning courses. Opponents could raise "philosophical" objections to "forced voluntarism" as a way of defeating a program whose academic substance and student outcomes raised few objections, and whose ultimate aims concerned citizenship rather than voluntarism.

This practical history suggests it may be prudent to defer the question of whether civic service learning should be a universal requirement until a variety of courses have been offered, revised, and evaluated. This strategy also permits faculty, students, and the community to become 
involved with, even enthusiastic about the program, and creates incentives from the bottom up to support integrating a requirement into the curriculum.

\section{Civic or Philanthropic?}

As we have noted, there are two distinctive justifications for service learning which, while they may be mutually reinforcing in certain ways, nonetheless pose contradictory choices and yield different pedagogical strategies. The philanthropic view emphasizes service as an exercise in altruism-the nurturing of giving either in terms of paying back (William Buckley's "gratitude") or in terms of a kind of noblesse oblige of people lucky enough to be educated. This approach is in the tradition of nineteenth-century thinking about charity and emphasizes character-building and a kind of compensatory justice where the well-off feel obligated to help the less advantaged.

The civic view, on the other hand, emphasizes mutual responsibility and the interdependence of rights and responsibilities, and it focuses not on altruism but on enlightened selfinterest. The idea is not that the welloff "owe" something to the less fortunate, but that free democratic communities depend on mutual responsibility and that rights without obligations are ultimately not sustainable. Here the focus is on the nurturing of citizenship and the understanding of the interdependence of communities. The civic approach also encourages an educational partnership between college and community, with the community actively involved in defining its own needs as well as the role service will play in the education of students (see question 6 below).

The first view is captured by the statement: "I am obliged to help others less fortunate than myself, and it will do my character good to do so!"' The second, by the statement: "I cannot flourish unless the communities to which I belong flourish, and it is my (enlightened) self-interest to become a responsible member of those communitieswhether they are my school, my neighborhood or my nation (or perhaps even my world)."

\section{For Credit or Not?}

The only way to guarantee the academic integrity of service learning is to offer full academic credit including extra credit for the community service practicum. Credit allows instructors to make serious academic demands and to enforce service participation. It also assures that students who are employed or participating in extra-curricular activities will not be prevented by their schedules from participating in service learning courses. Offering credit also justifies mandatory courses by guaranteeing students that

\section{The Rutgers program} begins with an alternative thesis: that educational institutions are learning communities, not service agencies, and that the primary justification for service programs has to be pedagogical.

their participation will receive credit towards graduation, thus making a service learning component a "graduation requirement."

Credit here is not a "reward" for what otherwise would be "voluntary" service; it is an acknowledgement of academic work (with a practicum) undertaken and successfully executed. Regular grades or pass-fail options can be used, although we have preferred regular grades for the classroom component and pass-fail for the additional service credit.

Finally, when a grade and a credit are offered for the classroom component of the course, students and faculty alike are persuaded that experiential learning need not be less than rigorous, and that reading and writing assignments will have to be taken as seriously as in any regular academic course.

\section{Single Course or Multiple Choice?}

A service learning program can develop a single central course (often in political science) which, in effect, "services" an entire college or university; or it can nourish a panoply of courses geared to certain common minimal standards but adapted to the needs and pedagogical requirements of different majors, schools, and programs.

At Rutgers, we began with the idea of a single course, but quickly discovered that variations based on departmental and program differences were far more compelling to students and faculty. Thus, the Rutgers program today offers as many as a dozen different courses teaching civic responsibility in a service learning context. All courses contain a "core" set of themes relating to democratic community and citizenship, but each variation is designed to reflect the professional needs and disciplinary concerns of particular departments, programs, and schools. For example, courses have been offered to meet the differing needs of performing arts students, business school students, honors students, social science majors, English majors, law school students, Douglass (women's) College students, urban campuses (Newark and Camden) and so on. In some cases, these are variations on a basic political science course, in others, they are new courses developed for specific schools or departments.

The adaptability to specific program needs of this approach has proved far more successful in meeting the conditions of a large university than a single course would have. On the other hand, it seems clear that in a small, more homogeneous college setting, a single course might turn out to be a more effective choice. The temptation to make a course or several courses exclusively political science offerings will be great, both because such courses are about political and civic education and because many faculty will feel only social scientists understand the issues. But in reality, issues of prejudice, liberty, community, responsibility, power, and equality can be found in the hard sciences as well as in the arts, in literature, and in other programs. For this reason, it is a good idea to try to involve faculty and departments outside of the social sciences in developing both courses 
and teaching resources for service learning.

\section{The Community: \\ Partner or Client? \\ "Us" or "Them"?}

A college or university that approaches the community with the offer of service from students needs to carefully consider how it understands that community and its relationship to the service learning program.

Because we determined that service learning was primarily an educational tool for our students, and because we regarded the university as inadequate to act as a social agency, we approached the community as a partner in education rather than a set of clients to be served. We said, in effect, "we come not so much to help the community, though perhaps we can do that, but to ask for your help in educating our students. Will you be our partners in education? If you will, we might be able to help a little with some of the community's challenges now, and we can promise a citizenry down the road far more likely to be capable of dealing with those problems."

This candor helped reduce exaggerated expectations on the part of our students and the community, and it also created a dignifying relationship of equity. In this reciprocal relationship between student volunteers and community, students serve in order that they might learn from citizens in the community surrounding them, and local citizens accept students' service so that they can contribute to their education.

Too often, to students, "the community" is nothing more than the problem community-a "them" which "we" can help but to which we do not belong. Partnership underscores mutual interdependence and helps create an understanding of "community" not as those with problems but as the group to which we all belong.

\section{Service in Groups or by Individuals?}

Most community service has been organized around individuals serving community groups. But there is an alternative: students can be organized into small teams or platoons, working together to serve community agencies. By making the experience of community a part of the organization of the class and of the service team, students get a better sense of the meaning of group responsibility, reciprocity, interdependence, and cooperation (or conflict). Students in teams are able to share and compare their service experiences, supplementing the faculty-student and community-student learning environment with a peer education experience.

The Rutgers program has been built on the team approach, and while students have complained that their own work is sometimes sublimated in the problems of others, we believe teamwork is one of the program's most significant merits.

\section{Faculty: To Serve or Not to Serve?}

A common and difficult question raised frequently by students is, "If we have to do service, why don't the faculty have to? Especially the faculty teaching this course!?"' It seems obvious that where faculty teaching the classroom component of a service learning course also do service in common with students, the impact is greatest. However, it is also true that the university teaches and requires of its students many things that it does not ask faculty to do. In the area of community service, the reasons for linkage are obvious, but it may put an undue burden on the recruitment of faculty to a program many see as alien and few feel trained or competent to teach in to start with.

Part of teaching students responsibility may in fact be to show that a quid pro quo approach ("I'll serve if my teacher serves, I'll serve if I'm appreciated') is insufficient to citizenship. It would be nice if everyone -especially teachers-practiced all they preached, but the value of the practice is not attenuated by the incapacity of all of its teachers to live their teachings.

\section{Engendering Citizenship or Encouraging Critical Thinking?}

Service learning planners may feel pulled between the democratic need to socialize students into patterns of responsible community and effective citizenship and the academic need to develop critical thinking skills. To a degree, this is a false choice, since critical thinking is perhaps the most important single example of a vital civic skill. Nonetheless, it is true that service learning courses may be more tempted than most to adopt an hortatory or even celebratory tone. This is one of the most important reasons why service learning needs to inhabit a serious academic course where critical readings and critical discussions are the rule.

At Rutgers, we encouraged critics of service learning and mandatory community service (thoughtful libertarians for example) to bring their objections into the classroom and argue them openly. We offered readings from a classical liberal perspective that assailed "the tyranny of the majority" and other potential vices of otherwise successful communities, and we tried to balance reading assignments in a way that would counter the obvious predilections of the program in favor of certain models of community, citizenship, and democracy. Thus, in our course, Thoreau and Tocqueville counter Jefferson and Rousseau; multiculturalists battle defenders of the traditional canon; and the vision of community advanced by Robert Bellah is challenged by the short stories of Shirley Jackson and Ursula LeGuin.

In the long run, the success of service learning programs as serious components of a for-credit undergraduate education depend on the critical depth and intellectual compass of courses. Only when democracy is subjected to full democratic debate in the classroom will real civic education take place.

\section{Planning a Program: Who Participates?}

It is easier in the short run for committed administrators and/or faculty to introduce service learning programs into a hostile college environment, but in the long run only those programs that draw students in at the very outset of the planning process and engage them in every step of development will be truly successful. Initially, students will distrust new programs and anticipate hypocrisy. Their participation in the planning process not only 
assuages their fears on this score, but guarantees them a genuine voice. In the long term, their participation will create a far healthier climate on campus for operating a service learning program.

\section{Conclusion}

Since its founding at the turn of the century, the American Political Science Association has had as one of its primary aims the making of better ctizens and promoting a dynamic civic education in American schools. It is no coincidence that political scientists are at the forefront in the movement to connect public and community service to a revitalized curriculum of civic education. We have tried to lay out the conceptual framework and strategic thinking behind efforts at Rutgers and at Baylor University to nurture these aims by incorporating service learning into the core academic curriculum. We also offer a sample syllabus from a political science service learning course (see page 240). Finally, we have each written more extended essays on the issues of civic education and service learning: Battistoni in his "The Civic Education of Future Generations," Public Leadership Education, Volume 5 (Kettering Foundation), 1992, as well as in his book Public Schooling and the Education of Democratic Citizens (Mississippi, 1985); Barber in his new book, An Aristocracy of Everyone: The Politics of Education and the Future of America (Ballantine, 1992). Moreover, we are assembling a service learning reader and workbook called Community Service and Education for Democracy: A Teacher/ Student Sourcebook to be published by Kendall-Hunt in the spring of 1993, which we hope will be of real use to faculty and students wishing to nurture successful service learning courses.

As we have already noted, the Rutgers pilot program is only one among many new efforts at colleges and universities around the country. Moreover, Campus Compact has made civic learning and pedagogy a new focus of their efforts on behalf of college community service. Service learning, in turn, is only one example of a number of approaches that, without abandoning the intellectual integrity of autonomous educational institutions, attempt to give practical meaning to the pedagogical philosophy that places the teaching of citizens at the center of liberal education-education for liberty. In the choices we have made at Rutgers and have explained here, we believe we have integrated service into the classroom in a fashion that promotes the cognitive, communicative and moral dispositions needed by citizens in a working democracy-dispositions indispensable to the survival of our free society.

In a vigorous democracy capable of withstanding the challenges of a complex, often undemocratic, interdependent world, creating new generations of citizens is not a discretionary activity. Freedom is a hothouse plant that flourishes only when it is carefully tended. Without active ctizens who see in service not the altruism of charity but the responsibility of citizenship on which liberty ultimately depends, no democracy can function properly or, in the long run, even survive. Without schools that take responsibility for what goes on beyond as well as in the classroom, and that work to remove the walls that separate the two worlds, students will continue to bracket off all that they learn from public life and keep their lives at arm's length from what they learn.

Community service is not merely a good idea; or as William F. Buckley has suggested, a way to repay the debt owed our "patrimony." It is an indispensable prerequisite of citizenship and thus a condition for democracy's survival. The Rutgers program and others like it offer a model that integrates liberal teaching, experiential learning, critical reflection, community service, and citizen education into a pedagogy of freedom. It also suggests a legislative strategy for the new administration, with its keen interest in the civic uses of service, for establishing a national service program without raising up still one more elephantine national bureaucracy. Require service of all Americans, but permit the requirement to be implemented through service learning programs housed in schools and universities-and, for those not in the school system, through other local institutions such as $4-\mathrm{H}$ or the
YMCA/YWCA or the Chamber of Commerce. Employing the nation's schools and colleges as laboratories of citizenship and service might at once offer an attractive way to develop civic service opportunities for all Americans and help educate the young to the obligations of the democratic citizen. And if political scientists lead the way in developing this experiential civics curriculum, we not only will be serving democracy but restoring to our teaching institutions and our profession the civic mission that defines our most admirable inclinations.

\section{Appendix}

\section{The Rutgers Program}

These ten choices were crucial to us in developing the Rutgers program over the last four years. Today, that program has engaged more than 800 students, who have contributed 55,000 hours of community service in the setting of nearly two dozen service learning courses. These courses span twelve academic and professional disciplines. Each course contains the "core" civic education framework, including required readings and writing assignments focused on issues of community, responsibility, citizenship, diversity, rights, and democracy, as well as a for-credit service placement; however, specific courses are adapted to the disciplinary concerns and professional needs of the departments and programs where they are offered. The political science department has developed a basic citizenship course devoted to issues of diversity, inequality, and justice as they are affected by service and community. A "Writing and Community Literacy" course, offered through the English Department at Newark and the Urban Affairs Department in Camden, uses issues of literacy as a lens through which to examine civic and community themes. Students are trained to serve as literacy tutors to community residents of all ages, ranging from elementary school "reluctant" readers to out-of-school adults preparing for high school equivalency exams.

Still another course offered in the Mason Gross School of the Arts (Rutgers' arts conservatory) brings Rutgers students into community afterschool arts programs and then challenges those Rutgers students back in the classroom to confront the social responsibilities of artists in a democratic society, and the obligations of society to artists. Issues of censorshp, funding, artistic freedom, and the politics of artistic expression become a path to broader issues of 
citizenship and democracy in this class.

These are only a few of the many courses being offered. We look forward in time, if not to a general requirement, to a relevant service learning course in every academic and professional program at Rutgers. As a partner in the New Jersey Academy for Community Service and Service Learning (established under the leadership of the New Jersey Department of Higher Education and funded by the National Service Commission), the Walt Whitman Center at Rutgers will develop curricula, training programs, teacher workshops, and implementation, dissemination, and assessment instruments. With the support of the Surdna Foundation, the Whitman Center is also sponsoring a nationwide working group of democratic theorists and practitioners, which will develop new conceptual frameworks for the relationship between service learning, community and citizenship, as well as working papers and a civic literacy evaluation test.

Finally, in the belief that democratic community must be modelled and experienced within the university as well as in service placements on the outside, the Rutgers program sponsors a Community Service House, home to 42 students of different backgrounds who share a commitment to service and citizenship. The House is self-governing, with students learning civic skills through active participation in creating rules and reaching agreement on common problems as well as through community service projects. This residence is proof to students that they not only serve many different communities but also constitute one.

The Rutgers "pilot" program (although it is much more than that, and certainly is more developed than most others) is nevertheless only one among dozens of such programs in the making around the country. It has been enormously successful, despite the absence of inside resources and of a faculty tradition of service learning. Our preliminary evaluations suggest that in undertaking community service in the setting of serious academic courses focused on democratic citizenship, students become better participants in and servers of their communities, more committed and knowledgeable citizens, and also better learners. Problems and contradictions-the libertarian who feels unfairly coerced, the separatist who dislikes working in an interracial setting-are transformed by service learning into opportunities for critical discussion and growth. And the personal interactions, the commitments to service, the perspectives on diversity (race, gender, age, sexual orientation) lived in student community placements and critically discussed in classrooms all become resources for building a vibrant community. It is too soon for us to judge, but these tendencies suggest that when Rutgers students who have participated in service learning go on to graduate and take their places in the larger society, they will be active citizens capable of establishing a thriving participatory culture.

\section{Suggested Readings in Civic Education and Community Service}

Barber, Benjamin R. 1992. An Aristocracy of Everyone: The Politics of Education and the Future of Democracy. New York: Ballantine Books.

Boyer, Ernest, and Fred Hechinger. 1981. Higher Learning in the Nation's Service. Washington, DC: Carnegie Foundation on the Advancement of Teaching.

Buckley, William, Jr. 1990. Gratitude: Reflections on What We Owe to Our Country. New York: Random House.

Dewey, John. 1916. Democracy and Education. New York: Macmillan.

Eberly, Donald J. 1988. National Service: $A$ Promise to Keep. Rochester, NY: John Alden Books.

Eberly, Donald J., and M. Sherraden, eds. 1990. The Moral Equivalent of War: $A$ Study of Non-Military Service in Nine Nations. New York: Greenwood Press.

Danzig, R., and P. Szanton. 1986. National Service: What Would It Mean? Lexington, MA: Lexington Books.

James, William. 1910. "The Moral Equivalent of War." International Conciliation, no. 27.

Evers, William M., ed. 1990. National Service: Pro and Con. Stanford, CA: Hoover Institution Press.

Janowitz, Morris. 1983. The Reconstruction of Patriotism: Education for Civic Consciousness. Chicago: University of Chicago Press.

Moskos, Charles. 1988. A Call to National Service: National Service to Country and Community. New York: Free Press.

Salmond, John A. 1967. The Civilian Conservation Corps, 1933-1942: A New Deal Case Study. Durham, NC: Duke University Press.

\section{Service Learning Syllabus}

This syllabus will also appear as a reader to be published by Kendall-Hunt in September 1993.

Part I: Citizenship in a Democracy

\section{A. Citizenship and Democratic Community}

Arendt, Hannah. "The Public Realm," from The Human Condition (1958).

Dewey, John. "Search for the Great Community," from The Public and Its Problems, pp. 143-54 (1927).

Mansfield, Katherine. "The Garden Party," from The Short Stories of Katherine Mansfield, pp. 534-49 (1937).

Jefferson, Thomas. "Summary View of the Rights of British America," "A Bill for Establishing Religious Freedom," "The Declaration of Independence," "Letter to James Madison, January 30, 1787," "Letter to John Adams, October 13,1813,"
"Letter to Samuel Kerchival, July 12, 1816," in Selected Writings.

Rousseau, Jean-Jacques. Selections from The Social Contract (1912 edition).

Whitman, Walt. Selections from Democratic Vistas (1873).

B. Citizenship and the Psychology of Belonging

Bellah, Robert, et al. Habits of the Heart, selections (1985).

Dostoevski, Fyodr. "The Grand Inquisitor," from The Brothers Karamazov (1927).

Emerson, Ralph Waldo. "Society and Solitude" (1870).

James, William. "The Moral Equivalent of War" (1910).

Kemmis, Daniel. Community and the Politics of Place, pp. 64, 70-82 (1990).

Monette, Paul. Borrowed Time: An AIDS Memoir, selections (1988).

Weil, Simone. The Need for Roots, pp. 43-52 (1952).

\section{Citizenship, Morals and Responsibility}

Aristotle, The Politics, Book III, Chapter 5. Thucydides. "Pericles' Funeral Oration," from The Peloponnesian War.

Barber, Benjamin R. "Neither Leaders Nor Followers: Citizenship Under Strong Democracy" (1985).

Boyte, Harry C. "Practical Politics." The Atlantic (1993).

Lincoln, Abraham. "Springfield Boys' Lyceum," "First Inaugural," "Second Inaugural," "Gettysburg Address," "House Divided," from Complete Works (1894).

Barber, Benjamin R. "The Reconstruction of Rights," The American Prospect (1991).

D. Citizenship and Service

Clinton, William J. "National ServiceNow," New York Times (February 28, 1993).

Selections from Visions of Service (1993).

Part II: Challenges to Democratic Citizenship

A. Prejudice, Difference, and Inequality

Anzaldua, Gloria. Selections from Borderlands: La Frontera= The New Mestiza (1987).

Ellison, Ralph Waldo. Prologue from The Invisible Man (1947).

Jackson, Jesse. "Common Ground and Common Sense," speech delivered at the 1988 Democratic National Convention.

Kozol, Jonatha;n. Selections from Savage Inequalities (1991).

Lorde, Audre. "Age, Race, Class and Sex: Women Redefining Difference," from Sister Outsider: Essays and Speeches.

Okin, Susan Moller. Introduction from Justice, Gender and the Family (1989).

Pateman, Carole. "Feminism and Democracy," from The Disorder of Women (1989).

Sacks, Oliver. "The Revolution of the Deaf," The New York Review of Books (1988).

Steele, Shelby. 'I'm Black, You're White, Who's Innocent?" from The Content of Their Character (1990).

B. The Tyranny of the Majority

The Bill of Rights, U.S. Constitution (1791).

Continued on page 262 
novel is necessarily any less serious than yet another analysis of a work of political theory. X on Faulkner may be just as fruitful for political insights as $\mathrm{X}$ on Tocqueville; and $\mathrm{Y}$ on Bellow may be more interesting (and therefore more productive of further thinking on the part of the reader) than A on Rawls or B on Nozick on Rawls-again.

\section{References}

Beiner, Ronald. 1983. Political Judgment. London: Methuen.

Fishman, Ethan. 1989. Likely Stories: Essays on Political Fiction and Contemporary American Literature. Gainesville, FL:
University Presses of Florida.

MacIntyre, Alasdair. 1985. After Virtue: $A$ Study in Moral Theory, 2nd (corrected) ed. London: Duckworth.

Mallinckrodt, Anita M. 1987. The Environmental Dialogue in the GDR: Literature, Church, Party and Interest Groups in Their Socio-Political Context: A Research Concept and Case Study. Lanham, MD: University Press of America.

Rorty, Richard. 1989. Contingency, Irony and Solidarity. Cambridge: Cambridge University Press.

Taylor, Charles. 1989. Sources of the Self: The Making of the Modern Identity. Cambridge: Cambridge University Press.

Whitebrook, M. F. 1983. "Politics and Literature." News for Teachers of Political Science, Fall.

Whitebrook, M. F., ed. 1992. Reading Political Stories: Representations of Politics in Novels and Pictures. Lanham, MD: Row- man and Littlefield.

Yanarella, Ernest J., and Lee Sigelman, eds. 1988. Political Mythology and Popular Fiction. New York: Greenwood Press.

Zuckert, Catherine H. 1990. Natural Right and the American Imagination: Political Philosophy in Novel Form. Savage, MD: Rowman and Littlefield.

\section{About the Author}

Maureen Whitebrook is honorary research fellow in the department of politics at the University of Sheffield, England. She has written widely on the connections between politics and literature. Her latest work is editing and contributing to Reading Political Stories: Representations of Politics in Novels and Pictures. She is now working on a booklength study of the significance of narrative for political theory.

Continued from page 240

Amado, Jorge. "Domination," from The Violent Land.

de Tocqueville, Alexis. "The Tyranny of the Majority," from Democracy in America (1854).

Emancipation Proclamation (1863) and excerpts from the $13 \mathrm{th}, 14 \mathrm{th}$, and 15 th Amendments to the U.S. Constitution.

Jackson, Shirley. "The Lottery," from The Lottery and Other Stories (1948).

King, Martin Luther. "Letter from Birmingham Jail," from Why We Can't Wait (1964).

Melville, Herman. "The Trial of Billy Budd," from Billy Budd, Chapters 19-22.

Olsen, Tillie. Selections from Silences (1968).

Piercy, Marge. "Right to Life." (current)

Rand, Ayn. Excerpt from The Fountainhead.

Excerpts from U.S. Supreme Court cases of Korematsu v. U.S. (1944) and Gobitis v. Minersville School District (1940).

\section{To Serve or Not to Serve}

Thoreau, Henry David. "On the Duty of Civil Disobedience."

Excerpts from U.S. Supreme Court case Seeger v. U.S. (1965).

Leguin, Ursula. "The Ones Who Walk Away from Omelas," from The Winds Twelve Quarters (1975), pp. 275-84.

Wilkinson, Francis. "The Gay Cadet," from The Village Voice (March 13, 1990).

Chapman, Bruce. "Politics and National Service: A Virus Attacks the Volunteer Sector," from National Service: Pro and Con (1986).

Part III: Opportunities for Citizenship and Service

A. The School and the University

Barber, Benjamin. "The Civic Mission of the University," The Kettering Review (1989).

Barber, Benjamin. "What Our 47-Year-Olds Know," from The New York Times (1987).

Bloustein, Edward J. "Community Service: A New Requirement for the Educated Person," Commencement Address, May 1988.

Clinton, William J. "Address on National Service," Rutgers University, March 1, 1993.
Dewey, John. "The Democratic Conception in Education," from Democracy and Education.

Moffatt, Michael. "What College is Really Like" and "Community" from Coming of Age in New Jersey (1989).

Rosovsky, Henry. Selections from "University Governance," from The University: An Owner's Manual (1990).

D'Souza, Dinesh. "Illiberal Education," from The Atlantic (1991).

Morris, Michael. "Educating Citizens for a Multicultural Society, from Public Leadership Education: Skills for Democratic Citizenship (1990).

Stimpson, Catherine. "Meno's Boy: Hearing His Story-and His Sister's," from $A c a$ deme. (current)

B. Neighborhood and Nation

Addams, Jane. Twenty Years at Hull House (1910), selections.

Berger, Peter and Richard John Neuhaus. Selections from To Empower People: The Role of Mediating Structures in Public Policy (1977).

Evans, Sara and Harry Boyte. "The People Shall Rule,', from Free Spaces (1986).

King, Martin Luther. "On Being a Good Neighbor," from Strength to Love (1963).

Milk, Harvey. "A City of Neighborhoods"

(1978).

Roosevelt, Franklin Delano. Speech Announcing the Civilian Conservation Corps (1933)

Schaar, John. "The Case for Patriotism," from Legitimacy in the Modern State (1981).

de Tocqueville, Alexis. "Public Association," from Democracy in America (1854).

C. The World

Barber, Benjamin. "Jihad vs. McWorld," The Atlantic (March 1992).

Barry, Wendell, "The Body and the Earth," from The Unsettling of America (1977).

Easterbrook, Gregg and Evan Eisenberg, "The State of the Earth," from The New Republic (1990).

Kennedy, John Fitzgerald. Speech Announcing the Peace Corps (1961).
Excerpts from the Rio Summit Declaration. Mother Teresa. Words to Love By, selections (1989).

The anthology will also include the following poems as epigraphs for each section: Anna Akhmatova, "Untitled poem," from You Will Hear Thunder; Bertholt Brecht, "An Apologia" and "Son of the Insufficiency of Human Endeavor"; Nina Cassian, "A Man"; Thomas Hood, "Song of the Shirt"; Langston Hughes, "Let America Be America Again"; Anne Sexton, "After Auschwitz"; Walt Whitman, "I Hear America Singing."

\section{About the Authors}

\section{Benjamin R. Barber}

Benjamin R. Barber holds the Walt Whitman Chair of Political Science at Rutgers University, where he is director of the Walt Whitman Center for the Culture and Politics of Democracy. With Patrick Watson, he wrote the prize-winning $\mathrm{CBC}$ / PBS ten-part television series "The Struggle for Democracy,'" published by Little, Brown. His latest book is An Aristocracy of Everyone: The Politics of Education and the Future of America (Ballantine, 1992), to be published in France by Belin Publishers.

\section{Richard Battistoni}

Richard Battistoni is director, Civic Education and Community Service Program, Rutgers University.

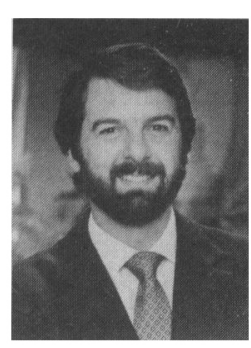

